\title{
BLACKWELL \\ The Faith of the Old Testament
}

A History

\section{W. H. SCHMIDT}

'Highly recommended for students ... it is surprising how much has been compressed into one single volume.' Society for Old Testament Study

Booklist

'Both the overall approach and his detailed discussions will provide much to talk about for a long time.' The Expository Times

320 pages, paperback $\mathbf{\$ 7 . 9 5}$ (0 631 15305 5)

'Signposts in Theology':

\section{Theology and Religious Pluralism GAVIN D'Costa}

How does religious pluralism affect Christianity's claim to absoluteness? Gavin D'Costa distinguishes three main types of response to this questionexclusivist, pluralist and inclusivist. He examines the views of representative figures from each of these 'schools' and suggests avenues for further thought.

164 pages, hardback \&19.50 (0631 145176)

paperback $\mathbf{6 6 . 9 5}(0631145184)$

\section{Theology, Death and Dying RAY S. ANDERSON}

The author places the discussion of death and dying firmly within a theological context, considering the work of Hick, Pannenberg, Thielicke and Macquarrie, in a book which will be invaluable to all those confronting the problem of death, whether personally, or as students, counsellors or clergy. 184 pages, hardback f19.50 (0631 14846 9)

paperback $\$ 6.95 \quad(0631148477)$

\section{Theology and the Problem of Evil KENNETH SURIN}

One of the most profound problems that theologians have to address is the presence of evil and suffering in the world and how this can be reconciled with the assertion of an omnipotent and morally perfect God. Kenneth Surin considers the way in which some major thinkers in different ages have attempted this reconciliation. 192 pages, hardback \&19.50 (0 631 14663 6) paperback $\$ 6.95$ (0631 14664 4)

\section{Basil Blackwell}

108 Cowley Road, Oxford OX4 1JF

Suite 1503, 432 Park Avenue South, New York NY 10016 


\section{CAMBRIDGE}

\section{Eberhard Jüngel}

An Introduction to his Theology

\section{J. B. WEBSTER}

This is the first introduction in any language to the work of Eberhard Jüngel. The study provides a comprehensive survey of his work as a New Testament scholar, systematic theologian and philosopher, focusing in particular on his discussions of theological and religious language, the role of Christology and questions of natural theology. 192 pp. $0 \quad 521307082 \quad \mathbf{\$ 2 0 . 0 0}$ net

\section{Medicine, Miracle and Magic in New Testament Times}

\section{HOWARD CIARK KEE}

This book sketches and illustrates in detail the range of understandings of the human condition and remedies for ills that prevailed when Jesus and the apostles - as well as their successors - were spreading the Christian message and launching Christian communities in the Graeco-Roman world. $168 p p .0 \quad 521323096 \quad \$ 19.50$ net Society for New Testament Studies Monograpb Series 55

\section{Cambridge University Press}

The Edinburgh Building, Shaftesbury Road, Cambridge CB2 2RU, England 


\section{NOTES FOR CONTRIBUTORS}

I. Contributions and books for review should be sent to the Editor, Professor S. R. Sutherland, King's College, Strand, London, wC2R 2LS.

2. Articles submitted to the journal should in general be between 5,000 and 10,000 words long, though articles outside these limits will be acceptable if there is some good reason for their exceptional length or brevity. Articles in two or more parts may occasionally be accepted provided each part is independently intelligible. They should normally be in English.

3. Submission of an article is taken to imply that it has not previously been published, or is not being considered for publication elsewhere.

4. Contributions should be clearly typed in double spacing, preferably on $\mathrm{A}_{4}$ paper, with a wide left-hand margin. The typescript should be prepared to accord as closely as possible with the typographical conventions of the journal.

5. Footnotes should be used sparingly: in general, to give sources of direct quotations, references to main authorities on disputable questions, and evidence relied on for a new or unusual conclusion. They should be numbered in one sequence throughout the article, and should preferably be typed in double spacing at the end of the article.

6. Contributors should keep one copy of the typescript for correcting proofs.

7. First proofs may be read and corrected by contributors provided that they can give the Editor an address through which they can be reached without delay and can guarantee to return the corrected proofs to the Editor, by airmail where necessary, within ten days of receiving them.

8. Correction should be kept to an absolute minimum. It should be confined to errors of the typist or printer unless the Editor authorises otherwise.

9. All contributions of articles receive 50 free offprints. Reviews will receive five or more offprints of their reviews.

ro. If rejected manuscripts are to be returned, stamps or international coupons should be sent to cover postage, but it would normally be simpler just to retain a copy.

II. Contributors of accepted articles will be asked to assign their copyrights, on certain conditions, to Cambridge University Press, to help protect their material, particularly in the USA. 


\section{Religious Studies}

\section{Volume 23 Number I March 1987}

\section{CONTENTS}

CLAYTON, JOHN

Religions, Reasons and Gods

page I

ZEMACH, EDDY M. AND WIDERKER, DAVID

Facts, Freedom and Foreknowledge

BALDICK, R. JULIAN

Massignon: Man of Opposites

PERRETT, ROY W.

Rebirth

ARTHUR, CHRIS

Phenomenology of Religion and the Art of Story-telling 59 COOK, ROBERT R.

God, Time and Freedom

REDMOND, MICHAEL D.

The Hammann-Hume Connection

STERN, JOSEF

Modes of Reference in the Rituals of Judaism MACKIE, MYRA BETH

Concerning 'Eschatological Verification Reconsidered' GARCIA, LAURA L.

The Essential Moral Perfection of God

C Cambridge University Press 1987

\section{CAMBRIDGE UNIVERSITY PRESS}

The Pitt Building, Trumpington Street, Cambridge CB2 IRP 32 East 57 th Street, New York, NY 10022 , USA 10 Stamford Road, Oakleigh, Melbourne 3166

Religious Studies is indexed in the Index of Religious Periodical Literature 